\title{
School Firearm Violence Prevention Practices and Policies: Functional or Folly?
}

\author{
James H. Price, PhD, MPH, FASHA ${ }^{1}$ and Jagdish Khubchandani, MBBS, PhD²
}

\begin{abstract}
Firearm injuries are the third leading cause of death for youth (14\% of all deaths of youth 1-19 years of age). In 2016, there were 3155 firearm deaths of youths $<19$ years of age. Recently, school firearm violence and school shootings have received increasing attention from school personnel, policymakers, and in the mass media. However, little is known about prevention and reduction of school firearm violence. The purpose of this narrative review is to describe the current practices regarding school firearm violence prevention and use of the disease prevention and health promotion framework to describe current practices and policies on school firearm violence prevention measures. A comprehensive review of the literature was conducted from the years 2000 to 2018 to search for school-based practices to reduce firearm violence. Hundreds of millions of dollars have been spent to harden schools. None of the currently employed school firearm violence prevention methods have empirical evidence to show that they actually diminish firearm violence in schools. To the extent that schools adopt ineffective firearm violence prevention measures, they are creating a false sense of security. School systems need to engage in collaborative research for evidence-based practices and policy advocacy through coalition building to address state firearm laws. Schools also need to expand their mental health services and cost-effective educational interventions for reducing violence (e.g., bullying, peer mediation, conflict resolution, etc.). Hardening of schools seems to be a questionable endeavor for most schools, given the dearth of evidence regarding effectiveness.
\end{abstract}

Keywords: school, firearm, violence, homicide, suicide, prevention

\section{Introduction}

$\mathbf{F}$ IREARM-RELATED MORBIDITY and mortality of youth include intentionally shooting another person (homicide), intentionally shooting one-self (suicide), and accidental shootings (unintentional). Firearm mortality accounted for 38,658 deaths in 2016, of which $3155(8 \%)$ were youth 0 19 years of age (Centers for Disease Control and Prevention [CDC] 2018). This statistic translates into $\sim 158$ classrooms of 20 students per classroom or 9 youths per day are killed with firearms. Firearm injuries are the third leading cause of death for youth. Firearm injuries accounted for $14 \%$ of all deaths among youth 1-19 years of age in 2015 (CDC 2018). Youths in 2016 killed with firearms were usually victims of firearm homicides $(n=1849$ or $58 \%)$, followed by firearm suicides $(n=1102$ or $34.9 \%)$, unintentional firearm deaths $(n=127$ or $4 \%)$, and legal intervention/undetermined $(n=77$ or $2.5 \%$ ). Firearm homicides among youth are more common in southern states and parts of the Midwest.

In contrast, firearm suicides among youth are more dispersed across the United States with a few western states having the highest rates. The youths most likely to be shot and killed are males ( $82 \%$ of all deaths; 4.5 times the rate of girls), older youths (ages 13-17 years; 12 times those who are younger), and racial/ethnic minorities (African Americans 10 times more than whites) (CDC 2018; Price et al. 2015).

There are far more youths (2.5 times) who end up in hospital emergency rooms from firearm trauma than those who die ( $\sim 7400$ youths/year or $20 /$ day). These nonfatal firearm injuries are more likely to occur in males $(84 \%$ or 5 times the rate of females), older youths ( $88 \%$ or 19 times the rate of younger youths), and racial/ethnic minorities (African Americans 47\%) (Fowler et al. 2017; Leventhal et al. 2014). Hospitalizations were most frequent for firearm assaults and infrequent for firearm suicide attempts (Herrin et al. 2018; Leventhal et al. 2014). This is, in part, due to the case fatality rate, which is $74 \%$ for firearm suicides compared with $14 \%$ for firearm assaults and $6 \%$ for unintentional firearm injuries (Fowler et al. 2017). Many of the youths who survive their hospitalizations for firearm-related injuries were most often from firearm assaults (62\%), and

${ }^{1}$ Department of Public Health, University of Toledo, Toledo, Ohio.

${ }^{2}$ Department of Health Science, Ball State University, Muncie, Indiana. 
two-thirds (67\%) were older youths (ages 15-19 years) (Herrin et al. 2018; Parikh et al. 2017). Younger youths ( $<15$ years) were more likely to be hospitalized for unintentional firearm injuries. Urban areas have the highest rate of firearm trauma hospitalizations. The cost for treating firearm trauma patients (ages 0-20 years) in 2010 was $\$ 330.6$ million U.S. dollars, and Medicaid paid for $46 \%$ of youth hospitalizations in 2006-2012, followed by private insurance (23\%), self-pay (15\%), and other (16\%) (Herrin et al. 2018; Parikh et al. 2017).

The aforementioned firearm trauma applies to all youths $\leq 19$ years of age. However, the focus of this article is on school firearm trauma and not on the more general issues of firearm violence or general violence in schools. The purposes of this narrative review are as follows: first, to place school firearm shootings within the larger context of youth firearm violence; second, examine the perceptions of key stakeholders regarding the roles of schools in reducing school firearm violence; third, examine the evidence of the effectiveness of currently used methods by schools to reduce firearm violence with the three levels of the traditional prevention paradigm; and fourth, suggest what the evidence on school firearm violence prevention implies for schools.

\section{Methods}

\section{Search strategy}

Electronic searches were carried out in the following databases: Google Scholar, CINAHL, and PubMed. The search results were limited to English-language peerreviewed literature for the years 2000-2018. When relevant articles were identified, their references were also hand searched to help ensure that all possible articles were found. Keywords such as "firearms," "guns," "homicide," "suicide," "school," "safety," "administrators," "parents," "staff," "violence," "adolescents," and "children" were searched. The order of keywords was changed in repeated searches across databases to extract the final pool of relevant studies. Two independent investigators (J.P. and J.K.) reviewed the final pool of studies to reach a consensus on inclusion of relevant articles. Discrepancies were sorted out with discussion.

\section{Search results}

A total of 630 publications were identified. After repeated filtration and search, most of the articles were not relevant to our study because they were not published in English, studies were conducted out of the United States, studies did not relate to school firearm violence, studies did not address firearm violence specifically and dealt with violence in general. A total of 89 journal publications that met our criteria were identified. A number of media reports have also been included in our review because of the recent events pertaining to this study and lack of scientific literature to confirm such events $(n=6$ media or website reports included). Many of the media reports were redundant, and only single instances of pertinent media reports have been reviewed.

\section{Results}

\section{Epidemiology of school firearm violence}

Table 1 indicates the total number of firearm homicides and suicides for youths of school age (5-18 years) and the proportion of the two major forms of firearm trauma committed at schools. The data indicate that on average $<2 \%$ of firearm homicides and $<1 \%$ of firearm suicides occur at schools (including on the way to or from school)

Table 1. Number of Homicides, Suicides, and Firearm Incidents Among Youths at and Away from School

\begin{tabular}{|c|c|c|c|c|c|c|}
\hline \multirow[b]{2}{*}{ School year } & \multicolumn{2}{|c|}{ Homicides $^{\mathrm{a}}$} & \multicolumn{2}{|c|}{ Suicides $^{\mathrm{a}}$} & \multirow{2}{*}{$\frac{\text { Firearm incidents }^{\mathrm{b}}}{\text { At school }}$} & \multirow{2}{*}{$\frac{\text { Access to gun }}{\text { At or away from school }}$} \\
\hline & At school & Away from school & At school & Away from school & & \\
\hline 2000-2001 & 14 & 1489 & 6 & 1487 & DNA & DNA \\
\hline 2001-2002 & 16 & 1497 & 5 & 1395 & DNA & DNA \\
\hline 2002-2003 & 18 & 1530 & 10 & 1321 & DNA & DNA \\
\hline 2003-2004 & 23 & 1442 & 5 & 1280 & DNA & DNA \\
\hline 2004-2005 & 22 & 1529 & 8 & 1463 & DNA & DNA \\
\hline 2005-2006 & 21 & 1668 & 3 & 1465 & DNA & DNA \\
\hline 2006-2007 & 32 & 1779 & 9 & 1287 & DNA & DNA \\
\hline 2007-2008 & 21 & 1722 & 5 & 1226 & DNA & 6.7 \\
\hline 2008-2009 & 18 & 1578 & 7 & 1333 & DNA & DNA \\
\hline 2009-2010 & 19 & 1377 & 2 & 1465 & 1749 & 5.5 \\
\hline 2010-2011 & 11 & 1328 & 3 & 1453 & 1685 & DNA \\
\hline 2011-2012 & 15 & 1186 & 5 & 1563 & 1333 & 4.7 \\
\hline 2012-2013 & 31 & 1155 & 6 & 1584 & 1556 & DNA \\
\hline 2013-2014 & 12 & 1038 & 8 & 1637 & 1501 & 3.7 \\
\hline 2014-2015 & 20 & 1148 & 9 & 1776 & 1463 & DNA \\
\hline 2015-2016 & DNA & DNA & DNA & DNA & 1576 & 4.2 \\
\hline
\end{tabular}

${ }^{\mathrm{a}}$ Indicates numbers for children ages 5-18 years.

${ }^{\mathrm{b}}$ Indicates number of incidents of students bringing firearms to or possessing firearms at a public school.

${ }^{\mathrm{c}}$ Indicates percentage of students ages 12-18 having access to a loaded gun, without adult permission, at or away from school.

DNA, data not available. 
(Musu-Gillette et al. 2018; National Center for Education Statistics 2018). Widespread media attention has caused the public and politicians to think of rare mass shootings at schools, such as Columbine High School (April 1999), Red Lake Senior High School (March 2005), Chardon High School (February 2012), Sandy Hook Elementary School (December 2012), and Marjory Stoneman Douglas High School (February 2018), just to name a few as typical of school shootings. In reality, shootings at schools generally and more specifically mass school shootings are very rare events (Wike and Fraser 2009). For the school year 20152016, there were $\sim 98,000$ public schools (including 6900 charter schools) and 34,000 private schools (Institute of Education Sciences 2018). If only one student is shot and killed per school shooting and there are 40 school firearm deaths per year (conservative figure), then the probability that any school would have a shooting fatality would be once every 3250 years $(130,000 / 40)$. Schools are one of the safest places for youths in every community (Price et al. 2015, 2016; Wike and Fraser 2009).

The prevalence of firearm-related incidents and youth carrying firearms in schools is higher than the prevalence of shootings and associated mortality in schools. According to various estimates, $1-10 \%$ of school-going students in the United States have carried a gun to school within the recent past. The rates differ based on geographic location, gender, race, age, and study time period. A common theme is the association of such gun-carrying behavior with student personal experiences, social contexts, and other multiple high-risk behaviors such as alcohol and drug use, criminal activity, behavioral problems, guns at home, peers with guns, and academic failure (Anderson and Sabia 2016; Cao et al. 2008; Cunningham et al. 2000; Hemenway et al. 2011; Kemal et al. 2018; Khubchandani and Price 2018a; 2018b; Kingery and Coggeshall 2001; Steinman and Zimmerman 2003; Wike and Fraser 2009).

While these are direct estimates from students in schools, other groups of individuals have also helped with the proxy measures of prevalence of firearm violence in schools. For example, in a national study of parents of high school students, almost a tenth of the parents $(9 \%)$ reported that a firearm-related incident had occurred in their child's school within the past 5 years (e.g., student found with gun on campus, bullet found, student threatened peers with guns, etc.) (Payton et al. 2017). Similarly, 17\% of high school principals in a national study reported a firearm-related incident on their school campus within the past 5 years (Price et al. 2016). The most comprehensive source of firearm incidents in schools across states comes from the U.S. Department of Education as shown in Table 1 (National Center for Education Statistics 2018). More than 1500 firearm-related incidents have been reported by public schools every year in the past decade. However, there is still a lot of discrepancy between the number of firearm incidents in schools and the number of students expelled from schools every year for possession of firearms (e.g., >3500 students were expelled in 2000-2001 academic year) (Kingery and Coggeshall 2001; Stader 2004). In addition, 2\% of schools in the United States took at least one serious disciplinary action for use or possession of a firearm or explosive device (National Center for Education Statistics 2018). There is an urgent need for a comprehensive firearm reporting and surveillance system that can be man- dated across school systems nationwide involving extensive collaborations across various stakeholders (see Key stakeholders' perceptions of the role of schools section) (Kingery and Coggeshall 2001; Modzeleski and Randazzo 2018; Wike and Fraser 2009; Yell and Rozalski 2000).

In the context of epidemiology of school firearm violence, it is also important to know the characteristics of those who are involved in homicides and suicides at school (Table 1). According to various studies, the most common characteristics of such students are that the majority $(>50 \%)$ of them are males, white, experienced bullying or rejection, acquired a firearm from home or from relatives and friends, premeditated or advance planned shootings with motives, usually not involved with gangs, and confided in individuals about their motives, or left a note or threatened someone or engaged in a violent act indicating risk of future violence (Anderson et al. 2001; O'Toole 2000; Schuster 2009; Vossekuil et al. 2002; Wike and Fraser 2009).

\section{Key stakeholders' perceptions of the role of schools}

Policymakers and school administrators can use the perceptions of key stakeholders to understand, explore, and possibly implement firearm violence prevention practices. An investigation of key stakeholders' perceptions would likely include eight nonmutually exclusive groups (Fig. 1). The first group to consider would be the parents of students. A study of 345 mothers of high school youths found that the vast majority perceived parents (99\%) and schools (96\%) nearly equally responsible for reducing school violence. The mothers believed that the primary factors contributing to school violence were as follows: parents do not teach children morals (84\%), parents who support aggressive behaviors $(78 \%)$, and lack of family involvement with their children (67\%) (Kandakai et al. 1999). Another study of 202 parents from Georgia found that parents' perceived lack of supervision, violent/abusive families, and a breakdown in family values were the leading causes of school violence (Bliss et al. 2006). Only one study specifically addressed parents' expectations of high schools in preventing firearm violence. Parents in this national study thought that the leading causes of school firearm violence were as follows: inadequate parental monitoring (73\%), peer harassment and/or bullying (58\%), inadequate mental health care services for youths (54\%), and easy access to firearms (51\%) (Payton et al. 2017). These parents also rated 37 policies that they thought might reduce school firearm violence, and they perceived the following policies to be most effective: install an alert system in schools (70\%), work with law enforcement to design an emergency response plan (70\%), create a comprehensive school security plan (68\%), require criminal background checks for all school personnel before hiring (67\%), and implement anonymous systems for students to report peer concerns regarding potential firearm violence $(67 \%)$. Interestingly, the majority of schools in the United States have adopted at least one of these or other visible security measures (Schuster 2009).

Since the year 2000, there have been four major studies examining the public's perceptions of firearm-related policies. Two of the studies did not have items specific to schools. However, they did address two items related to firearm safety of youth in 2013 and 2015. The majority of 


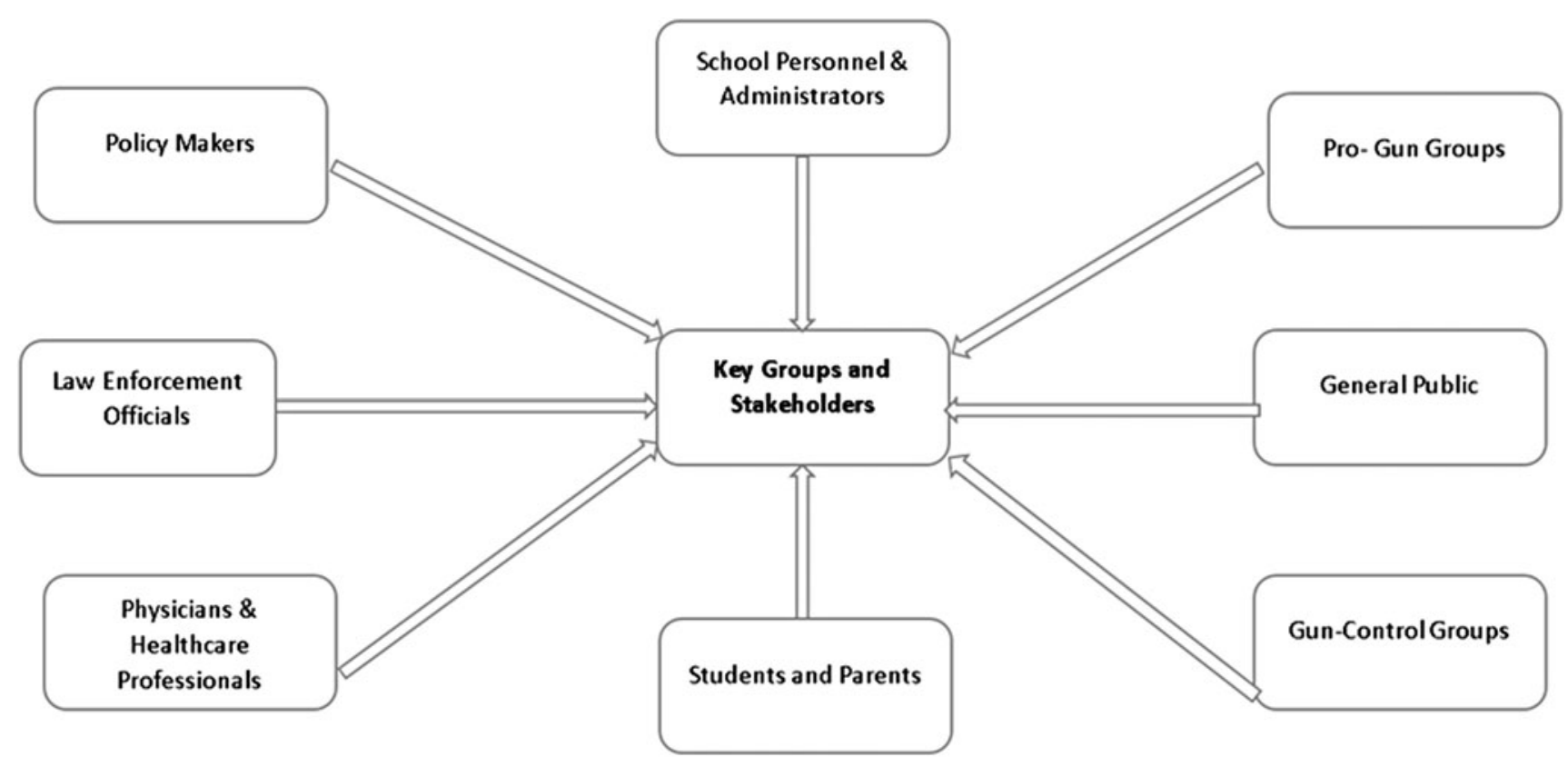

FIG. 1. Key stakeholders for school firearm violence prevention.

the public favored prohibiting people under the age of 21 from having a handgun ( $70 \%$ and $66 \%$, respectively); and requiring by law that persons lock up guns in their home when not in use to prevent handling by unsupervised youths (67\% and 69\%) (Barry et al. 2013, 2015). The same authors completed a third national study of adults' perceptions of firearm policies and this time, they added one item specifically related to schools. A minority of firearm owners (43\%) and nonfirearm owners (19\%) supported that people with a concealed carry permit should be able to carry their firearms on school (K-12 grades) grounds (Barry et al. 2018). Another national study by the Pew Research Center found that the vast majority of Americans identified easy access to illegally obtaining firearms $(86 \%)$ and family instability $(74 \%)$ as the leading factors in firearm violence (Parker et al. 2017). They also compared gun owners with children in the home with gun owners without children regarding safe storage of firearms. Those with children were more likely to support keeping all firearms locked up (66\% vs. 32\%, respectively), keeping all firearms unloaded (44\% vs. $27 \%$ ), and storing ammunition separately (43\% vs. 26\%). A majority of the parents claimed that they had talked with their children regarding firearm safety. For those who designated a political affiliation, $69 \%$ of Republicans and $26 \%$ of Democrats supported teachers and school officials carrying firearms in schools. Despite these views of parents, studies have found that having children at home does not always relate to safer storage of firearms at home (Connor 2005). It is noteworthy that the public's perceptions in the aforementioned studies may not be in agreement with other key stakeholders regarding school firearm violence prevention. For example, a national study of sheriffs found that less than half $(49.5 \%)$ supported child access prevention (CAP) laws and less than a third (30.7\%) supported a policy on making all new handguns childproof (Thompson et al. 2011).

There have been six published studies that have examined school principals' perceptions of violence and more spe- cifically, firearm violence prevention. A study of 336 Texas middle and high school administrators examined changes in school policies during the previous 5 years to reduce crime and firearm violence. Almost one-third (31\%) of school policy changes regarding school safety were in reaction to highly publicized events of school violence other than local violence (Snell et al. 2002). The vast majority of schools $(91 \%)$ had instituted zero-tolerance policies for firearm possession. Parental complaints and student concerns regarding violence in schools significantly affected school policies regarding safety. Another national study of 567 secondary school principals found that they believed the primary factors causing school violence were as follows: lack of parental supervision at home (63\%), lack of family involvement with schools (59\%), and exposure to violence in the mass media (54\%) (Price and Everett 1997). In contrast to the Texas study, the principals in the national study indicated that they personally saw a need to implement changes to their school programs to improve school safety. Only one national study directly examined principals' perceptions of school firearm violence-related issues (Price et al. 2016), and they perceived the main causes of school firearm violence to be inadequate parental monitoring (70\%), inadequate mental health services $(64 \%)$, peer harassment/bullying (59\%), and easy access to firearms $(50 \%)$. They perceived the following as effective strategies to reduce school firearm violence: criminal background checks of all school personnel (62\%), increase mental health services $(62 \%)$, require school resource officers (SROs) in schools (61\%), and reduce school bullying (59\%). Similar to this study, a regional assessment of school principals and law enforcement executives found that the majority of them supported SROs (Chrusciel et al. 2015). A small $(n=21)$ qualitative study of suburban school principals in New Jersey found that $71 \%$ endorsed having armed personnel in their schools. A significant portion of the principals in this study thought that school budgets should be dedicated 
primarily to academic technology and learning facilities rather than security systems (Kelly 2016). Finally, only one study explored school superintendents' perceptions of school violence prevention. The study of 60 rural superintendents in Georgia found that the majority had taken actions to "harden" their schools, including using SROs (70\%). A few (10\%) of them also reported removing firearms from students in the past year (Ballard and Brady 2007). Such varied views prevent a uniform understanding of the problem, and hinder effective strategies to address the problem of youth and school firearm violence. As a result, school personnel, parents, and students feel vulnerable and ambiguous regarding what should be done about firearm violence at schools. A small study from schools in Colorado found that the majority of principals $(63 \%)$ did not feel confident that the precautions in place were adequate if there was an armed intruder in the school and would like to be more prepared for such situations; but these individuals did not feel that additional armed personnel in their schools were warranted. The vast majority $(88 \%)$ also said "no" when they were asked if they would feel comfortable having armed school personnel other than licensed law enforcement officers (e.g., SROs) (Weiler and Armenta 2014).

While there are several studies regarding youth gun carrying prevalence and risk factors, only a few studies have explored school-going students' perspectives on firearm violence. The oldest study included in this narrative review was published in 2001, and was based on a survey of 342 high school students in New York City. A little less than a tenth $(8 \%)$ of the students believed that it was acceptable for youths to have guns, and almost a third of them thought of getting a gun (35\%) or had seen a gun at school $(30 \%)$. Students with guns at home were significantly more likely to express these views (Kahn et al. 2001). A national study of 1005 high school students found most wanted stricter policies regarding firearm sales, and they supported the following: make guns more difficult to obtain $(83 \%)$, mandatory firearm safety training to purchase a handgun $(89 \%)$, mandatory registration of all handguns at the time of purchase (96\%), require a license to purchase a handgun (90\%), all firearms must be sold with trigger locks $(86 \%)$, and adults should be held criminally responsible if their firearms are not stored properly and they are used by a youth (75\%) (Vittes et al. 2003). Another study of 1700 youth in Boston estimated gun-carrying behaviors and peer influence; youth in this study reported that it was easy for peers to obtain guns, and the prevalence of gun carrying was related to perceptions of the level of peer gun carrying. The study also found that students overestimated the prevalence of gun carrying by peers (Hemenway et al. 2011). A recent study of a nationally representative sample of 941 high school students found that three-quarters of the students $(74 \%)$ agreed that schools with properly trained and armed nonteaching staff are safer. However, only a little more than half $(55 \%)$ of these students agreed that a greater presence of armed citizens in society would reduce the risk of mass shootings. More than half $(60 \%)$ agreed that schools should have metal detectors for security purposes, and that there should be a ban on all assault-type weapons. However, less than half of the students $(47 \%)$ believed that stricter gun control laws would decrease gunrelated violence (Wu 2018).
Progun groups include a variety of organizations that provide educational materials and lobby (and fund) legislators to keep their agenda of minimal regulations on ownership and use of firearms. The National Rifle Association (NRA) is the most vocal of the groups, others include the National Shooting Sports Foundation (NSSF), Second Amendment Foundation, Gun Owners of America, and the National Association for Gun Rights, just to name a few. A study of financial contributions to federal legislators found that progun groups spent more of their donations on Republicans, males, and those from the South and western states for House members and similar patterns of spending in the U.S. Senate (Price et al. 2002). The NRA claims that more armed security in schools will make schools safer. President Donald Trump has echoed that sentiment and has supported arming of teachers (Minshew 2018).

In contrast, firearm control groups such as the Brady Campaign, Violence Policy Center, Everytown for Gun Safety, Giffords, and the Coalition to Stop Gun Violence, just to name a few, are known to more likely fund, at the national level, politicians who are female, Democrats, and those from the West or Northeast (Price et al. 2002). The basic tenets of these organizations revolve around attempting to reduce firearm mortality and morbidity by passing laws that could reduce such trauma. These organizations, based on published scientific studies as described in this review, would like the following to occur: ban assault weapons, large capacity clips, and bump stocks; require universal background checks on all purchases of firearms; require storage of firearms unloaded and locked; require firearm safety courses before purchase of handguns; raising the minimum age for gun ownership to 21 ; and better enforcement of existing gun laws.

\section{Prevention paradigm applied to school shootings}

There are three levels to the public health prevention paradigm for injuries and diseases (Fig. 2) (Modzeleski and Randazzo 2018; Price and Khubchandani 2017a; Wike and Fraser 2009; Yell and Rozalski 2000). At the primary prevention level for firearm injury by youths, we seek to prevent youth gaining access to firearms. Primary prevention is the most effective and cost beneficial level for eliminating school firearm violence. At the secondary prevention level, the goal is to detect and deter youths with access to firearms from bringing them into the school setting. The tertiary prevention level consists of reducing the amount of firearm injuries and deaths inflicted during school shootings. In other words, at the tertiary prevention level, armed personnel intervene while the school shooter is inflicting injuries on students and staff.

\section{Primary prevention}

The ideal method for eliminating school firearm violence by youths is to prevent them from ever gaining access to firearms. Unfortunately, studies have found an alarming rate of firearms accessible to youths (Price et al. 2015). A study in 2000 found that $43 \%$ of homes with youths reported having one or more unlocked firearms, and $9 \%$ kept the firearms unlocked and loaded (Schuster et al. 2000). Another study summarized the household prevalence of firearms and storage practices of firearms between 1992 and 


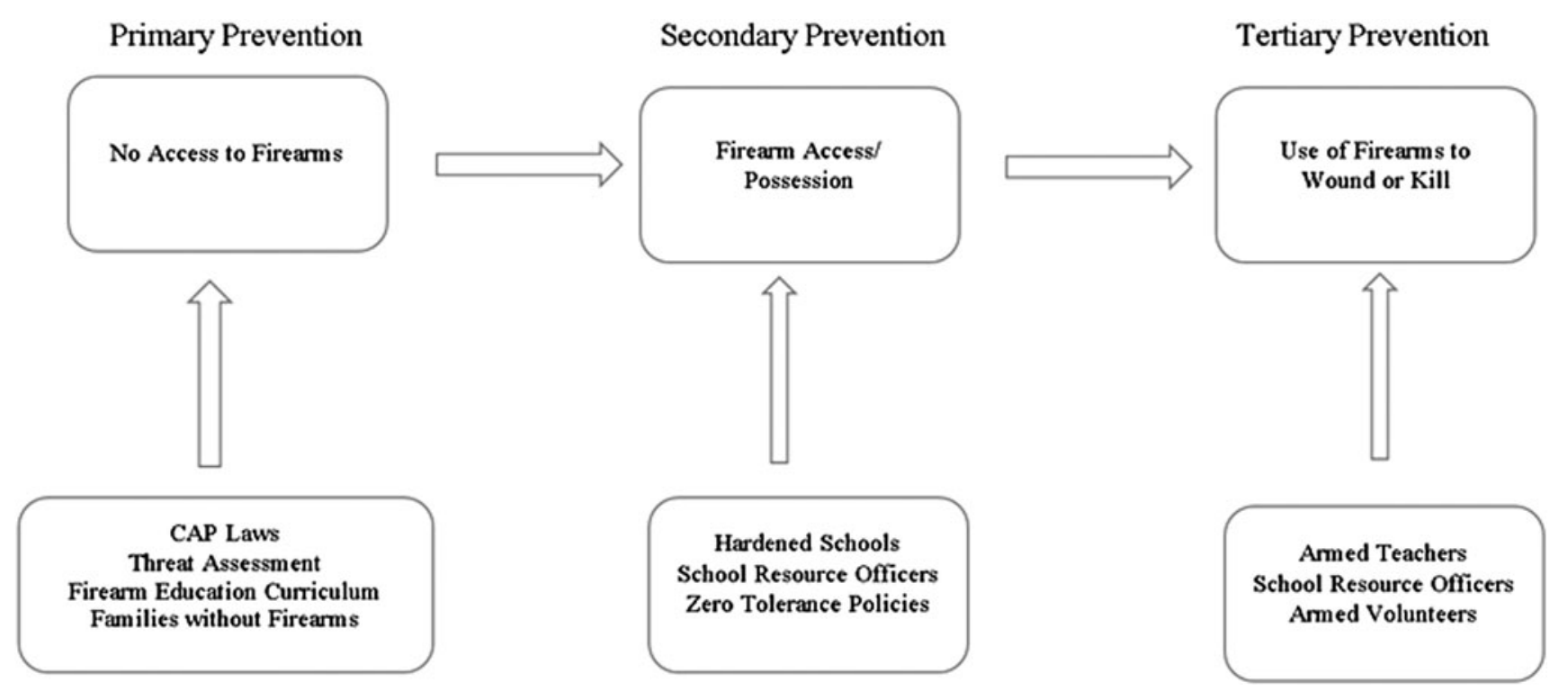

FIG. 2. Stages of prevention for school firearm violence by youths.

2002 (Johnson et al. 2004). They found that approximately one-third of the households had a firearm, half of which had handguns. Approximately $40 \%$ of the households with firearms and youths had at least one unlocked firearm and $10 \%$ had at least one firearm that was both unlocked and loaded. Regional studies further add to the variation-a study of Ohio adults found that $66 \%$ of firearm owners stored them unlocked, unloaded, and separate from ammunition. However, having children at home was not significantly associated with safer storage of firearms (Connor 2005). A more recent study found that about one-third of households had at least one firearm, $21 \%$ stored them loaded and unlocked, and it was estimated that $7 \%$ of youths in the United States (4.6 million) lived in those homes with loaded and unlocked firearms (Azrael et al. 2018). To compound this issue, a study of bullied students found that $15 \%$ of students who were both cyberbullied and traditionally bullied reported access to a loaded firearm without adult permission (9\% cyberbullied only and $5 \%$ traditionally bullied) (Simckes et al. 2017). In addition, youths who commit school shootings obtain their firearms from their homes or from the homes of relatives in $65 \%$ of the cases (Vossekuil et al. 2002). Furthermore, from a self-destructive perspective, youths who survived an almost lethal suicide indicated that it took them $<5$ min between the time they decided to kill themselves and their actual attempt (Simon et al. 2001). This is disturbing since research has shown that youths with a history of mental illness or those with a history of suicidality are as likely as those without such histories to report in-home access to firearms (Simon et al. 2001).

Firearm legislation is an important means of diminishing firearm morbidity and mortality in the United States (Murnan et al. 2004; Price and Khubchandani 2017b; Price et al. 2015). In general, states with strict enforcement of firearm laws have lower pediatric firearm injuries and mortality (Giffords Law Center 2018; Safavi et al. 2014). Only a few types of laws are specifically directed at affecting firearmrelated trauma in youths. CAP laws hold gun owners accountable for the safe storage of firearms by allowing prosecutors to charge adults who carelessly store their firearms (i.e., allow them to be accessible to youths). Twentyseven states and the District of Columbia (DC) currently have CAP laws (Giffords Law Center 2018). The strongest laws impose a criminal liability based on a penalty of a felony whether actual access to the firearm occurred (CA, $\mathrm{DC}, \mathrm{MA}$, and $\mathrm{MN}$ ). Other states require that a youth must actually gain access to the firearm whether the youth uses the firearm (HI, MD, NJ, and TX). Some states impose liability only if the youth carries or uses the firearm (CT, FL, IL, IA, NH, NC, and RI). There are 13 other states (CO, DE, GA, IN, KY, MS, MP, NV, OK, TN, UT, VA, and WI) that only prohibit adults from intentionally and/or recklessly providing a firearm to a youth. The last group of states' laws vary; some include all firearms, others only loaded firearms, and still others include only handguns. State CAP laws also vary by their definition of a "minor." In addition, the penalty for the acts of negligent storage varies by state (misdemeanor vs. felony) (Giffords Law Center 2018). CAP laws, their enactment, enforcement, and impact are also influenced by state sociopolitical climates and general firearm legislation. A study by Prickett et al. (2014) found that less than a tenth $(8 \%)$ of families owned firearms in states with CAP laws and stricter general firearm laws compared with almost a quarter (24\%) of families that owned firearms in states with weaker firearm laws and no CAP laws. Unsafe storage of firearms was also significantly higher in the latter group of families. This could potentially influence the level of youth firearm access and firearm morbidity or mortality (both in school and in the communities) across states depending on CAP laws along with general firearm-related laws and policies that influence firearm ownership and storage in households (Murnan et al. 2004; Prickett et al. 2014).

The effects of CAP laws have also been studied in relation to injury, homicide, suicide, and firearm-carrying behaviors among youth. For example, Anderson and Sabia (2016) found that CAP laws were associated with a $13 \%$ decrease in the rate of past month gun carrying and an $18 \%$ decrease in the rate at which students reported being 
threatened or injured with a weapon on school property. In this study, CAP laws were also associated with a reduced probability that students miss school due to feeling unsafe, but there was no observable impact on school-associated shooting deaths (Anderson and Sabia 2016).

Research has overwhelmingly found that CAP laws have reduced firearm deaths in youths. A study of 12 states with these laws in effect for at least 1 year found a $23 \%$ reduction in unintentional deaths in youths $<15$ years of age (Cummings et al. 1997). Another study by Webster et al. (2004) found that CAP laws reduced firearm suicides by $11 \%$ in youths 14-17 years of age. Gius (2015) also found an 11\% reduction in firearm suicides in youth ages 0-19 years in states with CAP laws. A study of CAP laws and nonfatal self-inflicted firearm injuries (both unintentional and suicides) found that the laws reduced these injuries by twothirds in the 11 states studied (DeSimone et al. 2013). Another study of felony CAP laws and unintentional firearm deaths found that such deaths were significantly reduced for youths $\leq 14$ (Webster and Starnes 2000) as did another study that found states with felony CAP laws had a $36 \%$ reduction in unintentional firearm deaths among youths $\leq 14$ (Hepburn et al. 2006). There have been three studies that examined CAP laws and homicides in youths, one study found an $11 \%$ reduction in youths $\leq 14$ and a second study found no effect (Cummings et al. 1997; Lott and Whitley 2001). A recent study on CAP laws and homicides suggested that CAP laws are associated with a $19 \%$ reduction in juvenile firearmrelated homicides, and the effect was driven by state enforcement of strict safe-storage standards (Anderson et al. 2018). While most of these studies focus on mortality, more data are needed on the effects of CAP laws on youth firearm injuries. One study from the National Kid's Inpatient Sample found no association between state CAP laws and incidence of pediatric accidental injuries and suicides (Lee et al. 2013). In contrast, a study from the same data found that stronger CAP laws were associated with reductions in all, self-inflicted, and unintentional pediatric firearm injuries across states (Hamilton et al. 2018). Various methods to assess the effects of CAP laws must be employed across populations and during various times. For example, contrary to the aforementioned success of CAP laws, a study by Ruddell and Mays (2004) found that CAP laws had no effect on accidental firearm deaths in juvenile populations.

Two other laws that have gained the attention of policymakers are minimum age requirements and bans on assault weapons with high-capacity magazines. Federal law currently requires licensed dealers not to sell or deliver handguns to those $<21$ years of age or long guns to youths $<18$ years of age (RAND Corporation 2018). Federal law prohibits youths $<18$ years of age from possessing handguns. Currently, only three states (HI, WA, and IL) restrict sales of firearms to those $\geq 21$ years of age. The research is inconclusive regarding the effects of minimum age requirements on firearm suicides, firearm homicides, and unintentional firearm deaths. The other laws banning assault weapons with high-capacity magazines have also had inconclusive evidence on firearm homicides and no evidence on the effects of firearm suicides or unintentional firearm deaths (RAND Corporation 2018).

The second form of primary prevention of adolescent firearm violence is threat assessment of preattack behaviors
(Meloy and O'Toole 2011; Price and Khubchandani 2017a). As mentioned earlier, the majority of youths involved in firearm violence in schools are likely to exhibit change in their behaviors. The following activities, when numerous, may indicate that the youth may commit a violent act: talking about having access to a firearm, exhibiting depressive symptoms, recent victimization by peers, substance abuse, living in a low emotional closeness family, parents not knowledgable of the youth's life, having past violent or aggressive behaviors, school suspensions/expulsions, change in school performance, preoccupation with violence (e.g., death, dismemberment), socially isolated loner, feeling persecuted, angry, and defensive are but a few of the changes that can occur. Given these circumstances, there are serious limitations to conducting formal threat assessments of potential youth firearm violence (Price and Khubchandani 2016, 2017a; Weisbrot 2008; Winer and Halgin 2016). First, few mental health professionals have been adequately trained to identify potentially violent youths. Thus, it is essential that threat assessment teams be trained on best practices regarding threat assessment procedures and practices, and to dispel misconceptions regarding the purpose of such teams. Second, most youths who make violent threats are unlikely to carry them out (braggadocios).

Thus, there is usually a high rate of false positives in threat assessments and potentially false negatives. Third, there is very limited evidence that threat assessments have resulted in fewer numbers of firearm violence incidents. Fourth, the cost-benefit ratio and return on investment for widespread threat assessments is not proven in relation to school firearm violence, and such measures may not be a high priority for schools given the numerous other issues that are considered of higher priority (and added to it the lack of resources). A recent review summarized findings from 15 years of lessons learned by using the federal model of threat assessment to prevent school shootings; there are still many unanswered questions and challenges with this approach, despite the fact that nearly half of the schools across the United States may have some type of threat assessment model in practice or in implementation stages (Modzeleski and Randazzo 2018). The third form of primary prevention is peer action in reporting "leakage." Leakage occurs when youths intentionally or unintentionally communicate, usually to peers or siblings, they are going to engage in a potentially violent act. Studies of secondary school shooters have found that between $58 \%$ and $100 \%$ made threatening statements to third parties (Meloy et al. 2001; O'Toole 2000). In the shooting cases studied by the U.S. Secret Service, $81 \%$ of the adolescent shooters had at least one person who knew the shooter was thinking about or planning the violence, and $59 \%$ of the shootings had two or more people who knew about the planning (Vossekuil et al. 2002). Leakage to peers occurs in both suicide and homicide, and students need to be educated about this issue. Teachers can include such issues in their health education classes and also teach students about firearm safety, emergency response, and practice how they would deal with a peer who said he was going to bring a gun to school or had behavioral problems and verbalized a desire to die or kill others (Brank et al. 2007; Gaughan et al. 2001; Price et al. 2015). Unfortunately, a "code of silence" seems to exist in most secondary schools. There is a fear of 
rejection and/or retaliation by students if they tell ("tattling") school personnel about student firearm threats or weapon carrying. At times, even serious problems that could endanger students and school personnel are not reported due to this code of silence (Kingery and Coggeshall 2001; Wike and Fraser 2009). A study of middle and secondary school students found that $40 \%$ of them had a peer tell them or another peer they were going to shoot someone, but only about one half of them claimed they would tell an adult (Gaughan et al. 2001). A study of willingness to report school weapon carrying by middle school youths found that $70 \%$ claimed they would report a student carrying a gun, but only $58 \%$ reported that they would report the student if it was a friend (Brank et al. 2007). Boys were less likely than girls to report a peer, and reporting was less likely the older the student. While the majority of attacks are premeditated and advanced threats have been made in many cases, we did not find any reports of formal education and its efficacy in students who might be preattack informed by peers that they were going to shoot someone. Thus, while such education seems plausible as a method of reducing school firearm violence, there is no evidence that such education or programs would reduce school firearm violence.

Educational interventions have also been discussed in relation to primary prevention of firearm violence. However, most of these programs have not been adequately evaluated (e.g., Steps to Prevent Firearm Injury, which is a physician to parent educational intervention; Straight Talk About Risks (STAR), which is a teacher to students K-12 curricula; Safe Alternatives and Violence Education, which is police to juvenile offenders education program; Teens on Target and Hands Without Guns, both of which are peer-topeer educational interventions) (Hardy 2002; Holly et al. 2019; Price et al. 2015). A study of the STAR curriculum, developed by the Center to Prevent Handgun Violence, is a skills building firearm safety program. The program covered skills regarding the danger of firearms, resisting peer pressure, preventing aggressive conflicts, and making good choices. The children were told not to touch a firearm, leave the area, and tell an adult. The weeklong curriculum was taught to youths 4-7 years of age. The curriculum was found to have no effect on the children's playing activities with a disabled semiautomatic firearm placed in the play area of the children (Hardy 2002). The children who handled the firearm often thought the gun was a toy. Only 8 of the 70 students stopped playing and reported the presence of a firearm to an adult. The second study in this area assessed the effectiveness of the NRA's Eddie Eagle Gun Safe Program. The focus of the program is to have youths "Stop. Don't touch. Leave the area. Tell an adult." The study included 11 students who were ages 4 and 5 . There were 5 sessions that lasted 10-15 min each and were given $>5$ days. One week after the program ended, the youths were assessed. The program was found to be effective in getting children to verbally repeat the gun safety message. However, a disabled firearm was placed in the play environment of the children, and none of them actually used the skills taught regarding not playing with the firearm and reporting its presence to an adult (Himle et al. 2004). A recent comprehensive review of school-based and community-based unintentional firearm injury safety education programs found that most of the programs increased the knowledge of youths (although not significantly). However, the programs did not increase the likelihood that children would not handle firearms when they encountered them in unsupervised situations (Holly et al. 2019). All of these educational programs were found to involve small samples with youths 4-9 years of age.

Very little instruction is given in relation to the teaching of firearm safety in schools. A national study of elementary school teachers found that $10 \%$ reported they currently taught firearm safety (Price et al. 2005). It is not surprising so little teaching regarding firearms was done since only $1 \%$ of the teachers indicated that they had any preservice training on firearm safety. This may also explain why $72 \%$ of the elementary teachers believed educating children to "Stop, Don't touch, Leave the area, Tell an adult" would be effective in getting children to avoid firearms. Another small study $(n=102)$ of Midwestern elementary school teachers found that $62 \%$ favored the teaching of gun safety in the elementary grades, but $54 \%$ thought that the teaching of such a topic should be done by police officers or trained military personnel rather than by elementary school teachers (Obeng 2010). The challenges are as follows: Do we have effective curricula to reduce youth firearm violence? Even if we do, who is supposed to teach the material? What would be the cost to do so? Would there be any legal, social, or political issues associated with such instruction in schools?

\section{Secondary prevention}

Secondary prevention assumes that youth will obtain firearms, and this form of prevention is an attempt to keep youths from using firearms at school (Fig. 2). Schools use a variety of practices to "harden" schools (make more resistant to attacks). Security measures currently being used by schools include the following: employ SROs, install video cameras, install bulletproof glass, require teachers and staff to wear IDs, use of metal detectors, classrooms that can be locked from inside, school-wide electronic notification systems, active shooter plans, locked access to schools, and relationships with local law enforcement agencies to patrol schools. According to the most recent available data (2015/ 2016 school year), the various security measures for the prevalence of firearm violence in schools were as follows: having a written plan for procedures to be performed in the event of an "active shooter" (92\%), monitored (94\%) or locked $(78 \%)$ doors to the building, security cameras $(81 \%)$, faculty and staff with IDs $(68 \%)$, electronic notification system in school $(73 \%)$, classrooms be locked from inside $(67 \%)$, lockers randomly checked $(53 \%)$, and random metal detector checks in high schools $(11 \%)$. In addition, while $57 \%$ of the schools have indicated that they have security staff present in their schools when examined for the security staff being present during all instructional hours of every school day, only $13 \%$ of primary schools and $46 \%$ of secondary schools have this level of coverage (Musu-Gillette et al. 2018).

Hardening of schools with visible security measures is an attempt to alleviate parental and student fears regarding school safety and to make the community aware that schools are doing something. However, visible school security measures are controversial as a means of making schools safer and reducing student concerns (Kingery and 
Coggeshall 2001; Minshew 2018; Tanner-Smith et al. 2018; Yell and Rozalski 2000). For example, SROs are hired by school systems to deter students from engaging in criminal behaviors. This concept is based on rational choice theory of behavior (similar to the benefits and barriers components of the Health Belief Model) (Tanner-Smith et al. 2018). Students who are school shooters are perceived as being youths who consciously weigh the benefits (shooting particular students) versus being caught by SROs and sent to prison or shot and killed (barriers). The flaw in this thinking in relation to school shooters is that many school shooters intend to die at the end of the shooting by suicide (either "suicide by cops" or "self-inflicted"). A study of schools in Texas found that schools with SROs had $45 \%$ of the students claiming students carried knives to school and $\sim 10 \%$ reported seeing other students carrying firearms to school (Brown 2006). In other words, SROs do not stop firearms from being brought to the schools. Another issue with SROs is the rare, but noteworthy, incidents of "heavy-handed" encounters where disruptive students may be slammed to the floor and handcuffed. Two factors may explain these rare events: first is the perceived roles that SROs play in their jobs (law and order enforcers, educators, counselors, or trusted adult confidants) (McKenna and White 2018); second is the zero-tolerance policies that result in automatic and harsh punishments for students. SROs who go to school with a "law and order" mentality may create an adversarial relationship with students and some teachers. A study of middle and high schools found that the presence of SROs resulted in fewer arrests for assault and weapon charges, but significantly more arrests for disorderly conduct charges when compared with schools without SROs (Theriot 2009). Another issue with SROs is the cost of full-time school coverage. Salaries for SROs range between $\$ 35,000$ and $\$ 45,000$ U.S. dollars per year. The financial cost of these full-time officers nationwide would be $\sim \$ 3.9$ billion U.S. dollars per year $(\$ 40,000 \times 98,300$ public schools), and this does not include the added costs to society if private schools $(n=34,000)$ are included. In a study of 12 urban schools of New York City where school-police partnership for the most dangerous and overcrowded schools was evaluated, it was found that despite increased police presence, students enrolled at these schools continued to experience higher than average problems linked directly to future criminality, lower attendance, and greater suspensions (Brady et al. 2007).

The zero-tolerance policies of schools usually result in mandatory expulsion (typically 1 year) of a student caught carrying a weapon. Zero-tolerance policies in schools now include a wide variety of offenses (e.g., fighting, stealing, possession of drugs, etc.). What used to be discipline issues handled by school teachers and administrators have now become crimes for which students are being arrested, often resulting in students dropping out of school (Suh and Suh 2007). The rigid rules of zero-tolerance policies have been characterized as "school to prison pipelines" that ensnare too many low socioeconomic and racial minority students, and are often unfair and unjust (Pigott et al. 2018; Stader 2004).

Two other visible security measures that have had limited examination of their success are metal detectors and random locker searches. A comprehensive review of efficacy of metal detector use in schools found mixed results (ranging from reduction in weapon carrying to school to greater concerns about safety and increase in students' perceptions of higher school disorder) (Hankin et al. 2011). One of the most successful studies reported that there was reduced carrying of weapons in New York City public schools when metal detectors were present compared with schools without metal detectors (78\% compared with 14\%). However, this assessment did not specifically report on the carrying of firearms. A newer concern regarding metal detectors is the issue of 3D-printed plastic firearms (Bryans 2015). A U.S. district court banned Defense Distributed from posting online an app that can direct the printing of 3D firearms. However, hundreds to thousands of downloads occurred before the ruling took place. In addition, the company is selling 3D printers with the app for printing guns on the printer. On August 9, 2018, a 23-year-old man in Utah was arrested for telling another university student that he was going to commit a mass shooting at a school using a firearm made from his 3D printer (Reavy 2018). This is an example of a type of weapon that would not be detected by metal detectors. We may see in the near future, a greater misuse of 3D printing of guns. A major legal concern is that metal detector searches and locker searches could be criticized for violation of student civil liberties. Youth's fourth amendment rights of protection from unreasonable searches and seizures by the state are worthy of consideration as they relate to creating a negative school climate. The majority of secondary students in some studies are not in favor of intrusive metal detector searches (Brown 2006; Hankin et al. 2011; Tanner-Smith et al. 2018). Similar challenges can be faced in courts by schools for any measures that appear to be intrusive and are considered visible security measures (Wike and Fraser 2009; Yell and Rozalski 2000).

In addition to the considerable expenses and diversion of school funds associated with visible security measures, the increased occurrences of criminal justice processing of students, and encroachment on student civil liberties, there is the possibility of "attack location drift." Attack location drift is the concept that as motivated student shooters become more aware of the fortress-like changes to schools, these shooters may alter their locations of attack to include places such as school buses, teacher parking lots, or athletic events (i.e., stadiums). As an example, on March 24, 1998, two middle school males pulled the fire alarm at the West Side Middle School in Arkansas, and as the students and teachers exited the school the two boys shot from an area adjacent to the school and killed 5 and wounded 10 others. In other instances, shooters were students who had legal access to school premises. In the worst situations, the student shooter can be armed, and could break through and move across all the visible security measures described above.

For all of these secondary prevention measures, we need to be aware that none of these interventions have been shown to unequivocally reduce or eliminate school shootings. Intuitively, it would seem as though the incorporation of several of these interventions as components of a comprehensive school security system should help reduce the rare occurrence of school shootings. However, despite the widespread adoption of secondary prevention measures across the majority of schools, parents, students, and school personnel continue to fear and anticipate shootings and do not feel adequately protected (Payton et al. 2017; Price et al. 
2016; Schuster 2009; Wike and Fraser, 2009). It is possible that these individuals know about or have heard of the potential failures of secondary prevention measures that have been implemented to create a sense of security without scientific evidence or external audits.

\section{Tertiary prevention}

Tertiary prevention as it relates to school firearm violence assumes that there is an active shooter on campus and the shooter must be stopped (Fig. 2). In other words, firearm trauma is usually not going to be prevented, only minimized. The focus of this stage of prevention is to have armed individuals in the schools to shoot and kill youth who are shooters. The groups of individuals who have been perceived as possible armed deterrents to school shootings include teachers, SROs, and trained community volunteers (often former military personnel or parents). The problem with this concept of a shootout in the public schools can best be seen with the following example. In the morning of January 3, 2018, a 15-year-old white male walked into Marshall County High School in Benton, Kentucky with a Ruger $9 \mathrm{~mm}$ semiautomatic pistol and within $10 \mathrm{sec}$ of shooting, he killed 2 and wounded 14 schoolmates. Armed school personnel would have needed to be in the exact same spot in the school as the shooter to significantly reduce this level of trauma. Ten seconds is too fast to stop a school shooter with a semiautomatic firearm when the armed school guard is in another place in the school. Beyond the question of arming school personnel, even in normal situations, school personnel do not always provide the level of close supervision that could possibly detect firearm-related incidents or events (Kingery and Coggeshall 2001).

School teachers have been nominated by the NRA and President Donald Trump as desired armed security in schools, and many states are already arming teachers (Minshew 2018). However, this concept has not received support from the majority of the studied school personnel, law enforcement executives, and other stakeholders. In addition, there are no national studies indicating support from school personnel or other stakeholders regarding this issue (Chrusciel et al. 2015; Minshew 2018; Rajan and Branas 2018; Rogers et al. 2018; Weiler and Armenta 2014). Teachers are dedicated public servants who perceive their jobs as educating, nurturing, and protecting the well-being of youths in their classes. Armed teachers confronted with a current or former student with a firearm may pose unique challenges (e.g., shooting someone you cared for). The problems likely to arise with all armed adults in schools are numerous (Chrusciel et al. 2015; Minshew 2018; Rajan and Branas 2018; Weatherby 2015). First, to suggest that the problem of firearms in schools can be solved by more firearms in schools is not grounded in scientific evidence. Second, there were armed guards employed at Columbine High School and Marjory Stoneman Douglas High School in Florida, where two of the most deadly high school shootings occurred. Third, if the armed person in a school is not in a police uniform and a shooting occurs, when the police arrive they may mistake the armed school personnel as the shooter. Fourth, SROs are usually paid for by both local law enforcement agencies and the local school system. These security expenditures create opportunity costs in the current climate of declining school budgets where teachers are already underpaid, schools lack sufficient staff (i.e., school psychologists, school nurses, and counselors), and inadequate teaching supplies are common (where teachers have to subsidize their students' school supplies). Fifth, there is the increased liability associated with firearm accidents and civil and criminal liability when innocent bystander students are shot in a school shootout. Evidence indicates that well-trained police officers shot the subjects they were aiming for $\sim 35 \%$ of the time (Kruzel 2018). Days after President Trump announced his support for armed teachers, there were reports of teachers accidentally firing shots resulting in student and school personnel with unintentional injuries. A frequently expressed concern in this regard is the bias toward racial and ethnic minority students when they are disproportionately more likely to be identified with problem behaviors. In addition, abilities of teachers as trained shooters are questionable; there are 26 states that let individuals with concealed carry permits to do so without demonstrating their shooting abilities (Mascia 2016). Sixth, often there is increased fear and resentment among students who have to go to school in an armed fortress and in a Pew Research Center poll, the majority of the adults (55\%) opposed the idea of teachers carrying firearms in schools (Parker et al. 2017). Seventh, armed personnel in schools give a false sense of security to parents and the larger community that school students and staff no longer have to worry about firearm violence in their schools. Finally, there are no parameters and guidelines currently in place to decide what proportion and to what extent should school personnel be armed to maximize the proposed benefits of such initiatives. The evidence to support tertiary prevention as a method of deterring school firearm violence incidents is lacking, and we believe it is unlikely to be forthcoming. However, there are likely to be occasions in which SROs may minimize the number of victims in an active shooter incident.

\section{Implications for school practice}

Millions of dollars have been spent by federal agencies such as the U.S. Department of Justice and U.S. Department of Education to fund and train SROs, for school staff training, and for law enforcement to help schools acquire measures for hardening schools and safety training of staff (Addington 2009). Hundreds of millions of additional dollars from state governments have been allocated to harden schools, and billions of dollars are needed to provide public schools with full-time SROs to reduce the likelihood that 40-50 students per year will be shot and killed at schools across the United States. Such massive expenditures on reducing school youth firearm mortality and morbidity will have little or no impact on the $98 \%$ of youth firearm homicides and $99 \%$ of youth firearm suicides that do not occur at schools.

There are two concerns associated with the aforementioned disproportionate spending to reap such limited benefits. First are the opportunity costs, meaning the expenditures for the prevention of school firearm violence means that there is a loss of potential gains from spending some or all of that money on alternative school issues (e.g., additional educators, better salaries, more instructional materials, or more 
mental health services). Second, policymakers, voters, and politicians are subject to implicit biases that can lead to over-reaction to highly publicized, but uncommon risks. It is common for people to overestimate small risks (e.g., students shot at schools) and underestimate larger risks (e.g., the major issue of youth firearm-related suicides across the nation). To maximize the usefulness of school budgets, administrators should develop school policies that they believe will result in the greatest good for the greatest number of students. However, political pressure, media sensationalization, and stakeholder views may make school administrators implement activities that will make it look like they are doing something to make their schools safer and end up ignoring best practices or avoid upsetting stakeholders and voters (Kingery and Coggeshall 2001). School firearm policy creation by any such influence is antithetical to evidence-based and to the extent that political pressures or media sensationalization result in the adoption of ineffective measures for schools, they are helping to create a dangerous environment by providing a false sense of security.

The reality in the United States today is that thousands of schools have incorporated SROs and visible security measures into their school safety plans. Besides the costs of using these measures, there is the issue of traditional student disciplinary problems being criminalized with more students ending up in the juvenile justice system. To avoid this problem, school systems should establish memorandums of understanding with local law enforcement agencies and use evidence-based practices for law enforcement and student discipline. There are some schools in which their environments (e.g., those in high-crime environments) may necessitate hardening of their structures. However, hardening of all schools seems unnecessary. As mentioned earlier, there is lack of evidence of success and students, parents, and school personnel continue to feel vulnerable, not adequately prepared, or live in fear due to the impression created by hardening of schools. Schools are becoming "war zones"; such climate may not be conducive for education.

There should be an expansion of schools that offer lowcost educational programs that address bullying, conflict resolutions, and racial/ethnic conflicts to mitigate school violence and more importantly violence in the larger community. Schools should also be educating students to tell an adult, and help save a life, when they learn of a peer threatening firearm violence. Mental health resources are critical to reducing youth violence and self-harm; schools should increase mental health services they offer to help students who have mental health problems or are at risk of serious mental illnesses and violence. However, this needs to be done with caution; there is not a lot of evidence to support that most students who commit school shootings have a diagnosable mental illness (even though, there could be personality or behavioral problems noted by people before shootings). Also, the mentally ill should not be stigmatized as violent and potential firearm offenders (Price and Khubchandani 2016). There are other numerous actions that schools can take to reduce firearm suicides (Price and Khubchandani 2017b).

Finally, students, educators, school systems, and state Departments of Education might better be served for reducing school shootings by focusing much of their resources and efforts on firearm policy advocacy. Educators need to be trained regarding collaborative policy advocacy, building coalitions, and using research evidence to inform practice (Price and Khubchandani 2017a; Price et al. 2015). Too many find it difficult to put themselves "out there" for perceived political causes. Policymaking does not happen quickly, people need to be involved for the "long haul," and it can be a method for social reform. Policymaking is a complex and nonlinear process that needs to mobilize public opinions and use scientific evidence to influence politicians and violence prevention practices. CAP laws with adequate penalties have been shown to reduce youth firearm violence. If youths cannot access firearms, they cannot shoot peers or themselves.

\section{Conclusions}

This comprehensive review of the literature from 2000 to 2018 regarding school firearm violence prevention failed to find any programs or practices with evidence indicating that they reduced such firearm violence. It could be the rarity of school shootings that makes it extremely difficult to prove that any combination of interventions in schools would be effective. School officials should not give in to political pressures to "do something" when that "something" is likely to be ineffective and wasteful of limited school resources. The adoption of ineffective measures to reduce school firearm violence may lull parents, school personnel, and students into thinking they no longer have to be concerned about their safety at school. A false sense of security is a dangerous environment that is currently being propelled by mass media, interest groups, and policymakers. More research funding is needed to pursue definitive answers regarding what is effective in substantially reducing school firearm violence and youth firearmcarrying or use behaviors.

\section{Author Disclosure Statement}

No competing financial interests exist.

\section{References}

Addington LA. (2009). Cops and cameras: Public school security as a policy response to Columbine. Am Behav Sci. 52, 1426-1446.

Anderson D, Sabia J. (2016). Child access prevention laws, youth gun carrying, and school shootings. National Bureau of Economic Research. Retrieved from https://papers.ssrn.com/sol3/papers .cfm?abstract_id=2757920 (accessed October 30, 2018).

Anderson DM, Sabia JJ, Tekin E. (2018). Child access prevention laws and juvenile firearm-related homicides. National Bureau of Economic Research. Retrieved from www.nber.org/papers/w25209 (accessed October 30, 2018).

Anderson M, Kaufman J, Simon TR, et al. (2001). School-associated violent deaths in the United States, 1994-1999. JAMA. 286, 2695-2702.

Azrael D, Cohen J, Salhi C, Miller M. (2018). Firearm storage in gunowning households with children: Results of a 2015 national survey. J Urban Health. 95, 295-304.

Ballard C, Brady L. (2007). Violence prevention in Georgia's rural public school systems: A comparison of perceptions of school superintendents 1995-2005. J Sch Violence. 6, 105-129. 
Barry CL, McGinty EE, Vernick JS, Webster DW. (2013). After Newtown-public opinion on gun policy and mental illness. N Engl J Med. 368, 1077-1081.

Barry CL, McGinty EE, Vernick JS, Webster DW. (2015). Two years after Newtown-public opinion on gun policy revisited. Prev Med. $79,55-58$.

Barry CL, Webster DW, Stone E, et al. (2018). Public support for gun violence prevention policies among gun owners and non-gun owners in 2017. Am J Public Health. 108, 878-881.

Bliss MJ, Emshoff J, Buck CA, Cook SL. (2006). Parents' perceptions of causes of and solutions for school violence: Implications for policy. J Prim Prev. 27, 265-280.

Brady KP, Balmer S, Phenix D. (2007) School-police partnership effectiveness in urban schools: An analysis of New York City's impact schools initiative. Educ Urban Soc. 39, 455-478.

Brank EM, Woolard JL, Brown VE, et al. (2007). Will they tell? Weapons reporting by middle-school youth. Youth Violence Juv Justice. 5, 125-146.

Brown B. (2006) Controlling crime and delinquency in the schools: An exploratory study of student perceptions of school security measures. J Sch Violence. 4, 105-125.

Bryans D. (2015). Unlocked and loaded: Government censorship of 3D-printed firearms and a proposal for more reasonable regulation of 3D-printed goods. Ind Law J. 90, 900-901.

Cao L, Zhang Y, He N. (2008). Carrying weapons to school for protection: An analysis of the 2001 school crime supplement data. J Crim Justice. 36, 154-164.

Centers for Disease Control and Prevention (2018). Web-Based Injury Statistics Query and Reporting System (WISQARS). Retrieved from www.cdc.gov/injury/wisqars/index.html (accessed July 2018).

Chrusciel MM, Wolfe S, Hansen JA, et al. (2015). Law enforcement executive and principal perspectives on school safety measures: School resource officers and armed school employees. Int J Polic Strat Manage. 38, 24-39.

Connor SM. (2005). The association between presence of children in the home and firearm-ownership and-storage practices. Pediatrics. 115 , e38-e43.

Cummings P, Grossman DC, Rivara FP, Koepsell TD. (1997). State gun safe storage laws and child mortality due to firearms. JAMA. 278, 1084-1086.

Cunningham PB, Henggeler SW, Limber SP, et al. (2000). Patterns and correlates of gun ownership among nonmetropolitan and rural middle school students. J Clin Child Psychol. 29, 432-442.

DeSimone J, Markowitz S, Xu J. (2013). Child access prevention laws and nonfatal gun injuries. South Econ J. 80, 5-25.

Fowler KA, Dahlberg LL, Haileyesus T, et al. (2017). Childhood firearm injuries in the United States. Pediatrics. e20163486.

Gaughan E, Cerio JD, Myers RA. (2001). Lethal Violence in Schools. (Alfred University Press, Alfred, NY.)

Giffords Law Center (2018). Child access prevention. Retrieved from https://lawcenter.giffords.org/gun-laws/policy-areas/childconsumer-safety/child-access-prevention (accessed October 30, 2018).

Gius M. (2015). The impact of minimum age and child access prevention laws on firearm-related youth suicides and unintentional deaths. Soc Sci J. 52, 168-175.

Hamilton E, Miller C, Cox C, et al. (2018). Variability of child access prevention laws \& pediatric firearm injuries. J Trauma Acute Care Surg. 84, 613-619.

Hankin A, Hertz M, Simon T. (2011). Impacts of metal detector use in schools: Insights from 15 years of research. J Sch Health. 81, 100-106.

Hardy MS. (2002). Teaching firearm safety to children: Failure of a program. J Dev Behav Pediatr. 23, 71-76.
Hemenway D, Vriniotis M, Johnson RM, et al. (2011). Gun carrying by high school students in Boston, MA: Does overestimation of peer gun carrying matter? J Adolesc. 34, 997-1003.

Hepburn L, Azrael D, Miller M, Hemenway D. (2006). The effect of child access prevention laws on unintentional child firearm fatalities, 1979-2000. J Trauma Acute Care Surg. 61, 423-428.

Herrin BR, Gaither JR, Leventhal JM, Dodington J. (2018). Rural versus urban hospitalizations for firearm injuries in children and adolescents. Pediatrics. 142, e20173318.

Himle MB, Miltenberger RG, Gatheridge BJ, Flessner CA. (2004). An evaluation of two procedures for training skills to prevent gun play in children. Pediatrics. 113, 70-77.

Holly C, Porter S, Kamienski M, Lim A. (2019). School-based and community-based gun safety educational strategies for injury prevention. Health Promot Pract. Retrieved from https://doi .org/10.1177/1524839918774571 (accessed October 30, 2018).

Institute of Education Sciences. (2018). National Center for Education Statistics, US Department of Education. Fast facts: Back to school statistics for 2018. Retrieved from https://nces.ed.gov/fastfacts/ display.asp?id=372 (accessed October 30, 2018).

Johnson RM, Coyne-Beasley T, Runyan CW. (2004). Firearm ownership and storage practices, US households, 1992-2002: A systematic review. Am J Prev Med. 27, 173-182.

Kahn DJ, Kazimi MM, Mulvihill MN. (2001). Attitudes of New York City high school students regarding firearm violence. Pediatrics. 07, 1125-1132.

Kandakai TL, Price JH, Telljohann SK, Wilson CA. (1999). Mothers' perceptions of factors influencing violence in schools. J Sch Health. 69, 189-195.

Kelly BP. (2016). Principals' perceptions of physical security and armed personnel: An exploration of New Jersey school administrators' views on active shooter counter measures. J Phys Secur. 9, 24-50.

Kemal S, Sheehan K, Feinglass J. (2018). Gun carrying among freshmen and sophomores in Chicago, New York City and Los Angeles public schools: The Youth Risk Behavior Survey, 20072013. Inj Epidemiol. 5, 12. Retrieved from https://link.springer .com/article/10.1186/s40621-018-0143-1 (accessed October 30, 2018).

Khubchandani J, Price JH. (2018a). Violent behaviors, weapon carrying, and firearm homicide trends in African American adolescents, 20012015. J Community Health. 43, 947-955.

Khubchandani J, Price JH. (2018b). Violence related behaviors and weapon carrying among Hispanic adolescents: Results from the national Youth Risk Behavior Survey, 2001-2015. J Community Health. 43, 391-399.

Kingery PM, Coggeshall MB. (2001). Surveillance of school violence, injury, and disciplinary actions. Psychol Sch. 38, 117-126.

Kruzel J (2018). Do more than 7 in 10 police bullets miss their mark, as this gun control advocate said? Retrieved from www.politifact.com/ truth-o-meter/statements/2018/may/25/shannon-watts/do-more-7-10police-bullets-miss-their-mark-gun-co (accessed October 30, 2018).

Lee J, Moriarty KP, Tashjian DB, Patterson LA. (2013). Guns and states: Pediatric firearm injury. J Trauma Acute Care Surg. 75, 50-53.

Leventhal JM, Gaither JR, Sege R. (2014). Hospitalizations due to firearm injuries in children and adolescents. Pediatrics. 133, 219-225.

Lott JR, Whitley JE. (2001). Safe-storage gun laws: Accidental deaths, suicides, and crime. J Law Econ. 44(S2), 659-689.

Mascia J (2016). 26 states will let you carry a concealed gun without making sure you know how to shoot one. Retrieved from www .thetrace.org/2016/02/live-fire-training-not-mandatory-concealedcarry-permits (accessed October 30, 2018). 
McKenna JM, White SR. (2018) Examining the use of police in schools: How roles may impact responses to student misconduct. Am J Crim Justice. 43, 448-470.

Meloy JR, Hempel AG, Mohandie K, et al. (2001). Offender and offense characteristics of a nonrandom sample of adolescent mass murderers. J Am Acad Child Adolesc Psychiatry. 40, 719-728.

Meloy JR, O'Toole ME (2011). The concept of leakage in threat assessment. Behav Sci Law. 29, 513-527.

Minshew LM. (2018). From the editorial board: On arming k-12 teachers. High Sch J. 101, 129-133.

Modzeleski W, Randazzo MR. (2018). School threat assessment in the USA: Lessons learned from 15 years of teaching and using the federal model to prevent school shootings. Contemp Sch Psychol. 22, 109-115.

Murnan J, Dake JA, Price JH. (2004). Association of selected risk factors with variation in child and adolescent firearm mortality by state. J Sch Health. 74, 335-340.

Musu-Gillette L, Zhang A, Wang K, et al. (2018). Indicators of School Crime and Safety: 2017. (NCES 2018-036/NCJ 251413). (National Center for Education Statistics, U.S Department of Education and Office of Justice Programs, U.S. Department of Justice, Washington, DC.)

National Center for Education Statistics (2018). Indicators of school crime and safety. Retrieved from https://nces.ed.gov/programs/ crimeindicators/index.asp (accessed October 30, 2018).

Obeng C. (2010). Should gun safety be taught in schools? Perspectives of teachers. J Sch Health. 80, 394-398.

O'Toole ME. (2000). The School Shooter: A Threat Assessment Perspective. (FBI Academy, Quantico, VA.) Retrieved from www.ncjrs.gov/App/Publications/abstract.aspx?ID=184799 (accessed October 30, 2018).

Parikh K, Silver A, Patel SJ, et al. (2017). Pediatric firearm-related injuries in the United States. Hosp Pediatr. 7, 308-312.

Parker K, Horowitz J, Igielnik R, et al. (2017) America's complex relationship with guns: An in-depth look at the attitudes and experiences of US adults. Retrieved from www.pewsocialtrends.org/ 2017/06/22/americas-complex-relationship-with-guns (accessed October 30, 2018).

Payton E, Khubchandani J, Thompson A, Price JH. (2017). Parents' expectations of high schools in firearm violence prevention. J Community Health. 42, 1118-1126.

Pigott C, Stearns AE, Khey DN. (2018). School resource officers and the school to prison pipeline: Discovering trends of expulsions in public schools. Am J Crim Justice. 43, 120-138.

Price JH, Dake JA, Thompson AJ. (2002). Congressional voting behavior on firearm control legislation: 1993-2000. J Community Health. 27, 419-432.

Price JH, Everett SA. (1997). A national assessment of secondary school principals' perceptions of violence in schools. Health Educ Behav. 24, 218-229.

Price JH, Khubchandani J. (2016). Firearm violence by the mentally ill: Mental health professionals' perceptions and practices. Violence Gend. 3, 92-99.

Price JH, Khubchandani J. (2017a). Adolescent homicides, suicides, and the role of firearms: A narrative review. Am J Health Educ. 48, 67-79.

Price JH, Khubchandani J. (2017b). Latina adolescents' health risk behaviors and suicidal ideation and suicide attempts: Results from the National Youth Risk Behavior Survey 2001-2013. J Immigr Minor Health. 19, 533-542.

Price JH, Khubchandani J, Payton E. (2015). Vision impaired or professionally blind: Health education research and firearm violence. Health Promot Pract. 16, 316-319.
Price JH, Khubchandani J, Payton E, Thompson A. (2016). Reducing the risks of firearm violence in high schools: Principals' perceptions and practices. J Community Health. 41, 234-243.

Price JH, Murnan J, Thompson AJ, et al. (2005). Elementary school teachers' involvement in firearm safety education. J Sch Health. 75, $105-111$.

Prickett KC, Martin-Storey A, Crosnoe R. (2014). State firearm laws, firearm ownership, and safety practices among families of preschool-aged children. Am J Public Health. 104, 10801086.

Rajan S, Branas CC. (2018). Arming schoolteachers: What do we know? Where do we go from here? Am J Public Health. 108, 860-862.

RAND Corporation (2018). The science of gun policy: A critical synthesis of research evidence on the effects of gun policies in the United States. Retrieved from www.rand.org/pubs/research_reports/ RR2088.html (accessed October 30, 2018).

Reavy P. (2018). Utahn threatened mass school shooting using 3-D printed gun, police say. Retrieved from www.deseretnews .com/article/900029678/utahn-threatened-mass-school-shooting-using3d-printed-gun-police-say.html (accessed October 30, 2018).

Rogers M, Lara Ovares EA, Ogunleye OO, et al. (2018). Is arming teachers our nation's best response to gun violence? The perspective of public health students. Am J Public Health. 108, 862-863.

Ruddell R, Mays GL. (2004). Risky behavior, juveniles, guns, and unintentional firearms fatalities. Youth Violence Juv Justice. 2, 342-358.

Safavi A, Rhee P, Pandit V, et al. (2014). Children are safer in states with strict firearm laws: a National Inpatient Sample study. J Trauma Acute Care Surg. 76, 146-151.

Schuster B. (2009). Preventing, preparing for critical incidents in schools. NIJ J. 262, 44-46.

Schuster MA, Franke TM, Bastian AM, et al. (2000). Firearm storage patterns in US homes with children. Am J Public Health. 90, 588-594.

Simckes MS, Simonetti JA, Moreno MA, et al. (2017). Access to a loaded gun without adult permission and school-based bullying. J Adolesc Health. 61, 329-334.

Simon TR, Swann AC, Powell KE, et al. (2001). Characteristics of impulsive suicide attempts and attempters. Suicide Life Threat Behav. 32, 49-59.

Snell C, Bailey C, Carona A, Mebane D. (2002). School crime policy changes: The impact of recent highly-publicized school crimes. Am J Crim Justice. 26, 269-285.

Stader DL. (2004). Zero tolerance as public policy: The good, the bad, and the ugly. Clearing House. 78, 62-66.

Steinman KJ, Zimmerman MA. (2003). Episodic and persistent guncarrying among urban African-American adolescents. J Adolesc Health. 32, 356-364.

Suh S, Suh J. (2007). Risk factors and levels of risk for high school dropouts. Prof Sch Couns. 10, 297-306.

Tanner-Smith EE, Fisher BW, Addington LA, Gardella JH. (2018). Adding Security, but Subtracting Safety? Exploring schools' use of multiple visible security measures. Am J Crim Justice. 43, 102-119.

Theriot MT. (2009). School resource officers and the criminalization of student behavior. J Crim Justice. 37, 280-287.

Thompson A, Price JH, Khubchandani J, Dowling J. (2011). Sheriffs' perceptions of firearm control polices. J Community Health. 36, $715-720$. 
Vittes KA, Sorenson SB, Gilbert D. (2003). High school students' attitudes about firearms policies. J Adolesc Health. 33, 471-478.

Vossekuil B, Fein RA, Reddy M, et al. (2002). The Final Report and Findings of the Safe School Initiative. (US Secret Service and Department of Education, Washington, DC.) Retrieved from https://training.fema.gov/programs/emischool/el361 toolkit/ assets/finalreport_safeschoolinitiative.pdf (accessed October 30, 2018).

Weatherby D. (2015). Opening the snake pit: Arming teachers in the war against school violence and the government-created risk doctrine. Conn Law Rev.48, 119.

Webster DW, Starnes M. (2000). Reexamining the association between child access prevention gun laws and unintentional shooting deaths of children. Pediatrics. 106, 1466-1469.

Webster DW, Vernick JS, Zeoli AM, Manganello JA. (2004). Association between youth-focused firearm laws and youth suicides. JAMA. 292, 594-601.

Weiler SC, Armenta AD. (2014). The Fourth R-Revolvers: Principal perceptions related to armed school personnel and related legal issues. Clearing House. 87, 115-118.
Weisbrot DM. (2008). Prelude to a school shooting? Assessing threatening behaviors in childhood and adolescence. J Am Acad Child Adolesc Psychiatry. 47, 847-852.

Wike TL, Fraser MW. (2009). School shootings: Making sense of the senseless. Aggress Violent Behav. 14, 162-169.

Winer JP, Halgin RP. (2016). Assessing and responding to threats of targeted violence by adolescents: A guide for counselors. J Ment Health Couns. 38, 248-262.

Wu S. (2018). The effects of cueing and framing on youth attitudes towards gun control and gun rights. Soc Sci. 7, 29.

Yell ML, Rozalski ME. (2000). Searching for safe schools: Legal issues in the prevention of school violence. J Emot Behav Disord. 8, 187-196.

Address correspondence to: Jagdish Khubchandani, MBBS, PhD Department of Health Science Ball State University Muncie, IN 47306

E-mail: jkhubchandan@bsu.edu 